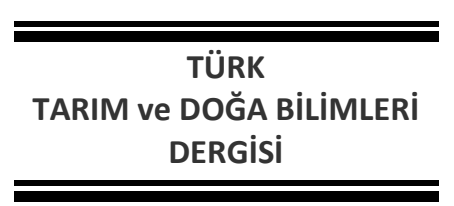

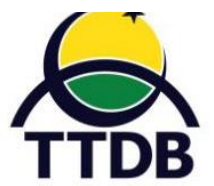

www.dergipark.gov.tr/turkjans

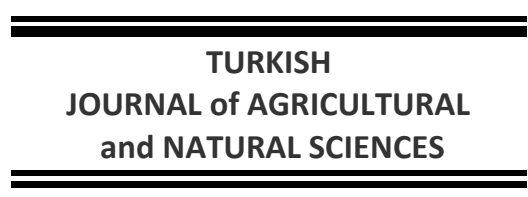

Araştırma Makalesi

\title{
Türkiye’nin Göller Bölgesi’nde Yetiştirilen Buğday Çeşitlerinin Bazı Kalite Özellikleri
}

\author{
Hülya GÜL ${ }^{1}$ Burhan KARA ${ }^{2 *}$ Sultan ACUN ${ }^{3}$ Sinem TÜRK ASLAN ${ }^{4}$ Ayşe ÖZTÜRK ${ }^{1}$ \\ ${ }^{1}$ Süleyman Demirel Üniversitesi Mühendislik Fakültesi Gıda Mühendisliği Bölümü, Isparta \\ ${ }^{2}$ Isparta Uygulamalı Bilimler Üniversitesi Ziraat Fakültesi Tarla Bitkileri Bölümü, Isparta \\ ${ }^{3}$ Amasya Üniversitesi Suluova Meslek Yüksekokulu Gıda İşleme Bölümü, Amasya \\ ${ }^{4}$ Pamukkale Üniversitesi Tavas Meslek Yüksekokulu, Denizli \\ *Sorumlu yazar: burhankara@isparta.edu.tr
}

Geliş Tarihi: 23.12.2019 Düzeltme Geliş Tarihi: 14.05.2020 Kabul Tarihi: 21.05.2020

\begin{abstract}
Öz
Bu çalışmada, Göller Bölgesi'nde yetiştirilen bazı yerel ve ticari buğday genotiplerinin öğütülmesi ile elde edilen unların bazı kalite özellikleri incelenmiştir. Göller Bölgesi'nde yer alan Isparta ve Burdur ili, ilçe ve köylerinden 7 adet yerel, 12 adet tescilli ticari çeşitler olmak üzere toplam 19 adet (9 tanesi ekmeklik, 10 tanesi makarnalık buğday çeşidi) buğday genotipi toplanmıştır. Buğday unu örneklerinde, kül, yaş öz, kuru öz, gluten indeks, sedimantasyon, gecikmeli sedimentasyon analizleri ile bu unlardan hazırlanan hamurlarda farinograf analizi, SMS/Kieffer hamur ve gluten uzayabilirlik analizi ve Dobraszczyk/Roberts hamur şişirme analizi yapılmıştır. Genotipler arasında, incelenen tüm özellikler bakımından istatistiksel olarak önemli farklar ( $p<0.01)$ saptanmıştır. En yüksek yaş gluten (\%36.17), kuru gluten (\%14.13), sedimantasyon $(40 \mathrm{ml})$ ve gecikmeli sedimantasyon $(49.3 \mathrm{ml})$ değerleri Bezostaja çeşidinde belirlenmiştir. Bezostaja buğday unu ile elde edilen hamurların reolojik özelliklerinin de diğer genotiplerden daha üstün olduğu saptanmıştır. Mirzabey, Sert Buğday (Bağıllı), Lavanta, Çeşit 1252 ve Kunduru-1149 çeşitlerinin süne zararına uğradığı tespit edilmiştir.
\end{abstract}

Anahtar kelimeler: Buğday unu, fizikokimyasal özellikler, reolojik özellikler

\section{Some Quality Characteristics of Wheat Varieties Grown in Lake District of Turkey}

\begin{abstract}
This study was carried out to examine the some quality characteristics of flours obtained by milling of some local and commercial wheat genotypes cultivated in Lakes District. For this purpose, totaly 19 different wheat genotypes ( 7 of them landraces and 12 of them commercial wheat cultivars) were collected from the province of Isparta and Burdur which are located in the Lake District of Turkey. Ash, wet gluten, dry gluten, gluten index, sedimentation, delayed sedimentation, farinograph, SMS/Kieffer dough and gluten extensibility and Dobraszczyk/Roberts dough inflation analysis were performed on wheat flour and dough samples prepared from these wheat varieties. Significant differences $(p<0.01)$ were found between genotypes in terms of all features examined. The highest wet gluten $(36.17 \%)$, dry gluten (14.13\%), sedimentation $(40 \mathrm{ml}$ ) and delayed sedimentation (49.3 ml) values were determined in Bezostaja genotype. Also the rheological properties of this genotype were higher than that of the other genotypes. Mirzabey, Sert Buğday (Bağıllı), Lavanta, Çeşit 1252 and Kunduru-1149 were damaged by the sunn pest.
\end{abstract}

Key words: Wheat flour, physicochemical properties, reheological properties

Giriş

Isparta ve Burdur illerininde içinde bulunduğu Akdeniz bölgesi, buğday çeşitliliği bakımından önemli gen merkezlerinden biridir
(Eser ve ark., 1987). TUik (2019) verilerine göre 2018 yılında Isparta'da 247776 dekar alanda 52727 ton durum buğdayı, 214461 dekar alanda 37422 ton diğer buğday çeşitleri 
(durum buğdayı hariç) üretimi yapılmaktadır. Burdur ilinde ise durum buğdayı 290559 dekar ekim alanı ve 81496 ton üretim, diğer buğday çeşitleri 205804 dekar ile 52631 ton üretim miktarına sahiptir. Göller Bölgesi'nde yer alan Isparta ve Burdur illerinde yetiştirilen buğday genotiplerinin un kalitesinin incelenmesi; hem mevcut durumun tespit edilmesi hem de mevcut çeşitlerden üstün özelliklere sahip olanların genetik materyal olarak muhafazası bakımından önemlidir (Dizlek ve ark., 2013 ve 2014).

Göller Bölgesinde uzun süredir yetiştirildiği düşünülen çeşitler ile ticari çeşitlerin bazı kalite kriterleri açısından karşılaştırılması ile bölgede yetiştirilen buğdayların özellikleri hakkında ön bilgi edinilebilir. Son yıllarda özellikle tüketicilerinde bilinçlenmesi, un ve unlu mamuller teknolojisi ve endüstrisinin gün geçtikçe gelişmesi, belirli kalite ve nitelikte olan buğdaylara gereksinimi artırmıştır. Buğday ve unların fiziksel ve kimyasal özellikleri, öz miktarı ve kalitesi, bileşimi ve reolojik özellikleri çevreden önemli ölçüde etkilenmektedir. Çevre, yumuşak ve sert buğdayların kimyasal ve reolojik özelliklerinde büyük değişim kaynağıdır (Hazen ve Ward, 1997). Farklı bölgelerde ve Göller yöresinde yerel buğday genotiplerinin yetiştiriciliği üzerine çalışmalar olsada, bu buğdayların un ve ekmeklik kalitesi üzerine bölgemizde yapılan bir çalışmaya ratlanmamıştır. Kara ve Akman (2008), Isparta yöresinde toplanan 15 yerel genotip ve 3 ıslah çeşidi kullanılarak yürütülen çalışmada bitkisel özellikler ve tane verimi bakımından genotipler arasında önemli farklılıkların çıktığını, ticari çeşitlerin yerel genotiplere göre daha yüksek verimli olduğunu, yerel genotiplerin ise verim potansiyelllerinin düşük olduğunu bildirmişlerdir. Topdemir (2004) Türkiye'de yetiştirilen bazı ekmeklik buğday çeşitlerinin un ve ekmeklik kalitesini belirlemek amacıyla, 17 adet ekmeklik buğday çeşidi arasında kimyasal ve teknolojik nitelikler bakımından farklılıklar görüldüğünü bildirmiştir.

$\mathrm{Bu}$ araştırmada, Göller Bölgesi'nde buğday tarımının yoğun olarak yapıldığı Isparta ve Burdur illerine bağlı ilçe ve köylerden (özellikle geleneksel modelde üretim yapan ve kendi ürününü tohumluk olarak değerlendiren başta yayla köyleri) toplanan 19 yerel ve ticari buğday çeşidinin bazı kimyasal ve teknolojik özellikleri incelenmiştir.

\section{Materyal ve Metot}

Göller Bölgesinin büyük bir bölümünü Burdur ve Isparta illeri oluşturduğu için araştırmada buğday örneklerinin toplanması işlemi bu illerden yapılmıştır. Tarım il ve ilçe müdürlüklerinin kayıtlarından ve bölge hakkında uzman kişilerin yönlendirmesiyle buğday tarımının yoğun olarak yapıldığı özellikle geleneksel modelde üretim yapan ve kendi ürününü tohumluk olarak değerlendiren başta yayla köyleri olmak üzere değişik bölgelerden buğday örnekleri toplanmıştır. Buğday örneklerini temin etmek amacıyla; Isparta il merkezi, merkez köyleri ve buğday tarımının yapıldığı ilçelerden; Yalvaç, Gelendost, Yenişarbademli, Şarkikaraağaç, Eğirdir, Senirkent, Atabey, Uluborlu, Keçiborlu ve Gönen ile bu ilçelerden seçilen 5 farklı köye gidilmiştir. Aynı şekilde Burdur ili il merkezi, merkez köyleri ve ilçelerden; Bucak, Ağlasun, Altınyayla, Gölhisar, Yeşilova, Karamanlı, Kemer, Tefenni, Çavdır, Çeltikçi ve bu ilçelere bağı farklı köylere gidilerek yerel ve ticari buğday örnekleri toplanmıştır. Toplanan ekmeklik ve makarnalık buğday genotiplerinin numaralandırılmaları ve isimleri Çizelge 1'de verilmiştir.

Çizelge 1. Göller Bölgesi'nden toplanan buğday çeşitleri

\begin{tabular}{llll}
\hline Örnek No & Ekmeklik Buğday Genotipleri & Örnek No & Makarnalık Buğday Genotipleri \\
\hline 1 & Gerek 79 & 9 & Ankara 98 \\
2 & Bezostaja & 10 & Sert Buğday (Bağıllı) \\
3 & Cumhuriyet 75 & 11 & Kırmızı Kazmalı Buğday \\
4 & Sönmez 2001 & 12 & Levante \\
5 & Hatay 86 & 13 & Kırmızı Buğday \\
6 & Osmaniye & 14 & Burgaz \\
7 & İmir 85 & 15 & Kızıltan \\
8 & Yunak & 16 & Kunduru-1149 \\
& & 17 & Çeşit 1252 \\
& & 18 & Gediz 75 \\
& 19 & Mirzabey \\
\hline
\end{tabular}


Buğday örnekleri yerel üreticilerden hasat edilen ve genellikle tohumluk olarak ayırdıkları kitleden, tüm buğday kitlesini temsil edecek şekilde, örnek alma yöntemine uygun olarak alınmıştır. Buğdaylar 10'ar kg'lık kısımlar halinde torbalar içerisine konularak Süleyman Demirel Üniversitesi Mühendislik Fakültesi Gıda Mühendisliği Bölümü Tahıl İşleme Teknolojisi Laboratuarına getirilmiş ve analiz edilene kadar oda koşullarında muhafaza edilmişlerdir.

\section{Buğday örneklerinin tavlanması ve öğütülmesi}

AACCI Metot No. 44-01.01 göre nem içeriği belirlenen buğday örneklerine $A A C C I$ Metot No. 26-95.01'de belirtilen miktarlara göre su ilavesi yapılarak soğuk tavlama işlemi (püskürtme ve karıştırma yöntemi ile) uygulanmıştır (AACCl, 2010). Örnekler tavlandıktan sonra 2 saat aralıklar ile karıştırılmış ve 24 saat sonra laboratuvar tipi dört valsli tavlı buğday öğütme değirmeninde (Ekin Gida, Ankara) ortalama \%60-65 randımanda öğütülmüştür. Öğütme sonrası unlar 3 hafta süreyle oda koşullarında olgunlaştırma amacıyla bekletilmiş ve daha sonra aşağıda belirtilen un analizleri yapılmıştır.

\section{Un analizleri}

Buğday örneklerinden elde edilen unlarda; kül (AACCI, 2010: Metot No. 08-01.01), yaş ve kuru gluten, gluten indeks (AACCI Metot No. 38-12.02), zeleny sedimantasyon (AACCl, 2010: Metot No: 56-60.01) ve gecikmeli zeleny sedimantasyon (Greenaway ve ark., 1965) analizleri yapılmıştır.

\section{Farinograf analizi}

Buğday örneklerinin öğütülmesi ile elde edilen unlardan hazırlanan hamurların farinogram değerleri Brabender marka farinograf cihazı kullanılarak, AACCI Metot No. 54-21.02 (AACCl, 2010)'ye göre belirlenmiştir.

\section{SMS/Kieffer hamur ve gluten uzayabilirlik analizi}

Farklı buğday çeşitlerine ait unlar ile hazırlanan hamurların Tekstür Analiz cihazında (TA.XT Plus, Stable Micro Systems Ltd., Godalming, Surrey, İngiltere) SMS/Kieffer hamur ve gluten uzayabilirlik probu (SMS/Kieffer Dough and Gluten Extensibility Rig) kullanılarak hamurun uzamaya karşı direnç (Rmax), uzayabilirlik (Ext) ve kurve altındaki alan (ARmax/Ext) değerleri ölçülmüştür (Kieffer ve ark., 1998). Bu yönteme ait parametrelerden ön test hızı $1.0 \mathrm{~mm} / \mathrm{s}$, test hızı $3.3 \mathrm{~mm} / \mathrm{s}$, son test hızı $10.0 \mathrm{~mm} / \mathrm{s}$, mesafe $75 \mathrm{~mm}$, trigger kuvvet tipi $5 \mathrm{~g}$ ve veri elde etme oranı ise 200 pps şeklindedir.

\section{Dobraszczyk/Roberts hamur şişirme analizi}

Hazırlanan hamurların; basınç (P:mm), uzama (L:mm) ve enerji (W: Joules * 10000) değerleri tekstür analiz cihazında (TA.XT Plus, Stable Micro Systems Ltd., Godalming, Surrey, Ingiltere) Dobraszczyk - Roberts hamur şişirme sistemi (Ön test hızı: $8.63 \mathrm{~cm}^{3} / \mathrm{s}$, test hızı: 26.70 $\mathrm{cm}^{3} / \mathrm{s}$, hacim: $2.000 .000 \mathrm{~mm}^{3}$, trigger hacmi: $30.000 \mathrm{~mm}^{3}$, kırma hassasiyeti: suyun 0.8 inch'i) kullanılarak belirlenmiştir (Chin ve Campbell, 2005).

\section{Istatistiksel analizler}

Elde edilen bulgular SPSS (Versiyon 16.0) istatistik programı ile Duncan çoklu karşılaştırma testine tabi tutulmuştur. Yapılan istatistiksel değerlendirmeler sonucunda ortalamalar arasındaki farklılıklar \%99 güven aralığına $(p<0.01)$ göre incelenmiştir.

\section{Bulgular ve Tartışma \\ Buğday unlarının kül, yaş gluten, kuru gluten ve gluten indeks değerleri \\ Göller Bölgesi'nden toplanan 19 buğday} genotipinin kül miktarları \%0.457 (Cumhuriyet75 ) ile \%0.837 (Kunduru-1149), yaş öz değerleri \%12.33 (Gediz-75) ile \%36.17 (Bezostaja) arasında değişmiştir. En yüksek yaş öz değerleri sırasıyla 2 (Bezostaja), 7 (Osmaniye) ve 15 (Burgaz) no'lu örneklerde; en düşük yaş öz değerleri ise 17 (Kunduru-1149) ve 19 (Gediz 75) no'lu örneklerde belirlenmiştir (Çizelge 2). Farklı lokasyon ve çeşitler üzerine yürütülen çalışmalarda buğdayın yaş gluten değerlerinin \%22.26-37.93 (Yağdı, 2004), \%15.12-27.42 (Sözen ve Yağdı, 2005) ve \%25.35 ile \%29.38 (Çoşkuner ve ark., 2011) arasında değiştiği bildirilmiştir.

Araştırmada kuru gluten değerleri ise; \%4.08 (Kunduru-1149)-\%14.13 (Cumhuriyet 75) arasında değişmiştir (Çizelge 2). Kara ve ark. (2009) Isparta koşullarında buğdayın kuru gluten oranının \%9.0-11.5, Kahrıman ve Egesel (2011) \%25.3-43.6 arasında değiştiğini ve Menderis ve ark. (2008) ortalama \%10.59 olduğunu bildirmişlerdir.

Un örneklerinde gluten indeks değerleri karşılaştırıldığında, en düşük gluten indeks değeri $(\% 0.20)$ yaş öz değeri de düşük olan 
Kunduru-1149 ve Mirzabey (\%3.44) çeşitlerinde belirlenmiştir. En yüksek gluten indeks değeri ise Ankara 98 (\%94.90), Cumhuriyet 75 (\%93.18), Bezostaja (\%91.80) ve İzmir 85 (\%91.56) çeşitlerinde belirlenmiştir (Çizelge 2). Ankara 98, Cumhuriyet 75 ve İzmir 85 çeşitlerinin yaş öz değerleri düşük olmasına rağmen gluten indeks değerleri yüksek bulunmuştur. Bu durum söz konusu buğday örneklerinin gluten kalitesinin iyi olduğunun bir göstergesi olarak kabul edilebilir. Kara ve ark. (2009) Isparta koşullarında buğdayın gluten indeks değerinin \%90.3-98.6, Menderis ve ark. (2008) \%48.08-99.7, Egesel ve ark. (2009) $\% 14.0-77.8$ ve Kahrıman ve Egesel (2011) \%43.7-94.3 arasında değiştiğini bildirmişlerdir.

Çizelge 2. Buğday unlarının kül, yaş gluten, kuru gluten ve gluten indeks değerleri ${ }^{(1)}$

\begin{tabular}{|c|c|c|c|c|}
\hline Buğday Genotipleri & Kül (\%) & Yaş Gluten (\%) & Kuru Gluten (\%) & Gluten Indeks (\%) \\
\hline \multicolumn{5}{|c|}{ Ekmeklik Buğday Genotipleri } \\
\hline Gerek 79 & 0.503 hij & $27.57 \mathrm{~cd}(1)$ & 9.35 bc & $66.40^{b}$ \\
\hline Bezostaja & 0.493 hij & $36.17^{a}$ & $14.13^{\text {a }}$ & $91.80^{a}$ \\
\hline Cumhuriyet 75 & $0.457^{j}$ & 22.23 ef & 8.40 cde & $93.18^{a}$ \\
\hline Sönmez 2001 & $0.547^{\mathrm{gh}}$ & 25.48 cde & 8.48 cde & $71.19 \mathrm{~b}$ \\
\hline Hatay 86 & $0.747^{b c}$ & $19.56^{f}$ & $6.53^{f}$ & $48.77^{c d}$ \\
\hline Osmaniye & $0.540 \mathrm{ghı}$ & $34.57^{\text {a }}$ & $10.83^{b}$ & $86.95^{a}$ \\
\hline İzmir 85 & 0.483 ij & 22.87 ef & 8.37 cde & $91.56^{a}$ \\
\hline Yunak & $0.580 \mathrm{fg}$ & 25.56 cde & 8.32 cdef & $73.71 \mathrm{~b}$ \\
\hline \multicolumn{5}{|c|}{ Makarnalık Buğday Genotipleri } \\
\hline Ankara 98 & $0.793 \mathrm{ab}$ & $20.70^{f}$ & 7.17 ef & 94.90 a \\
\hline Mirzabey & $0.663^{\text {de }}$ & $29.11 \mathrm{bc}$ & 7.02 ef & $3.44^{g}$ \\
\hline Sert Buğday (Bağıllı) & 0.670 de & 25.83 cde & 7.74 cdef & $20.06^{f}$ \\
\hline Kırmızı Kazmalı Buğday & $0.710^{c d}$ & $28.79 \mathrm{bcd}$ & $9.26 \mathrm{bcd}$ & $50.60^{c d}$ \\
\hline Levante & $0.817^{a}$ & 26.28 cde & 7.99 cdef & 26.53 ef \\
\hline Kırmızı Buğday & $0.700 \mathrm{~cd}$ & 24.79 de & $7.47 \mathrm{def}$ & $55.05^{c}$ \\
\hline Burgaz & $0.827^{a}$ & $32.50 \mathrm{ab}$ & $10.20^{b}$ & $67.36^{b}$ \\
\hline Kızıltan & 0.627 ef & $28.47^{b c d}$ & 6.80 ef & $45.84^{c d}$ \\
\hline Kunduru-1149 & $0.837^{a}$ & $14.54 \mathrm{~g}$ & $4.08 \mathrm{~g}$ & $0.20 \mathrm{~g}$ \\
\hline Çeşit 1252 & 0.533 ghı & $20.57^{f}$ & $6.96 \mathrm{ef}$ & $44.34^{d}$ \\
\hline Gediz 75 & $0.780 \mathrm{ab}$ & $12.33 \mathrm{~g}$ & $4.68 \mathrm{ef}$ & $32.85 \mathrm{e}$ \\
\hline
\end{tabular}

(1): Aynı sütunda aynı harf ile gösterilen ortalamalar arasında istatistiksel olarak fark yoktur

\section{Buğday unlarının sedimantasyon ve gecikmeli sedimantasyon değerleri}

Sedimantasyon değerleri açısından un örnekleri karşılaştırıldığında; en yüksek sedimantasyon değerine $40 \mathrm{ml}$ değeri ile Bezostaja çeşidinin sahip olduğu, bunu $30.3 \mathrm{ml}$ ile Osmaniye çeşidinin takip ettiği belirlenmiştir. Bezostaja ve Osmaniye dışındaki çeşitlerin sedimantasyon değerlerinin $9.3 \mathrm{ml}$ (Burgaz) ile $21.7 \mathrm{ml}$ (Yunak) arasında değiştiği dolayısıyla tamamının sedimantasyon değerinin düşük olduğu belirlenmiştir (Çizelge 3 ). Bir buğday ununun ekmeklik olarak değerlendirilebilmesi için sedimantasyon değerinin en az $20 \mathrm{ml}$ olması gerekir (Diepenbrock ve ark., 2005). Bu durumda Bezostaja, Osmaniye, Cumhuriyet 75 ve Levante çeşitleri haricindeki çeşitlerin sedimantasyon değeri dikkate alındığında ekmeklik kalitelerinin zayıf olduğu ifade edilebilir. Aydın ve ark. (2005) Samsun ve Amasya'da yaptıkları çalışmada farklı ekmeklik buğday çeşitlerinin sedimantasyon değerlerinin $26.3 \mathrm{ml}$ ile $54.5 \mathrm{ml}$ arasında değiştiğini, Reçber (2011) İzmir'de yürütttüğü çalışmada 20 buğday genotipinin sedimantasyon değerinin 11.7 ile $23.7 \mathrm{ml}$, Kahrıman ve Egesel (2011) ise 26.3 ile $62.7 \mathrm{ml}$ arasında değiştiğini rapor etmişlerdir. 
Çizelge 3. Buğday unlarının sedimantasyon ve gecikmeli sedimantasyon değerleri ${ }^{(1)}$

\begin{tabular}{lll} 
Buğday Genotipleri & $\begin{array}{l}\text { Sedimantasyon } \\
(\mathrm{ml})\end{array}$ & $\begin{array}{l}\text { Gecikm } \\
(\mathrm{ml})\end{array}$ \\
\hline Ekmeklik Buğday Genotipleri & & $15.3^{\mathrm{h}}$ \\
Gerek 79 & $16.3^{\mathrm{e}(1)}$ & $49.3^{\mathrm{a}}$ \\
Bezostaja & $40.0^{\mathrm{a}}$ & $27.7^{\mathrm{c}}$ \\
Cumhuriyet 75 & $21.3^{\mathrm{c}}$ & $18.0^{\mathrm{g}}$ \\
Sönmez 2001 & $18.3^{\mathrm{d}}$ & $10.0^{\mathrm{j}}$ \\
Hatay 86 & $11.0^{\mathrm{h}}$ & $43.3^{\mathrm{b}}$ \\
Osmaniye & $30.3^{\mathrm{b}}$ & $25.3^{\mathrm{d}}$ \\
İmir 85 & $21.3^{\mathrm{c}}$ & $19.7^{\mathrm{f}}$
\end{tabular}

Makarnalık Buğday Genotipleri

$\begin{array}{lll}\text { Ankara } 98 & 11.7^{\mathrm{gh}} & 12.3^{\prime} \\ \text { Mirzabey } & 11.0^{\mathrm{h}} & 5.0^{\prime} \\ \text { Sert Buğday (Bağılı) } & 17.0^{\mathrm{de}} & 5.3^{\prime} \\ \text { Kırmızı Kazmalı Buğday } & 16.7^{\mathrm{de}} & 13.7^{\prime} \\ \text { Levante } & 21.0^{\mathrm{c}} & 8.3^{\mathrm{k}} \\ \text { Kırmızı Buğday } & 12.7^{\mathrm{fgh}} & 10.7^{\mathrm{j}} \\ \text { Burgaz } & 9.3^{\prime} & 21.3^{\mathrm{e}} \\ \text { Kızıltan } & 12.0^{\mathrm{gh}} & 6.7^{\prime} \\ \text { Kunduru-1149 } & 13.3^{\mathrm{fg}} & 5.0^{\prime} \\ \text { Çeşit } 1252 & 14.0^{\mathrm{f}} & 5.0^{\prime} \\ \text { Gediz } 75 & 12.3^{\mathrm{fgh}} & 18.0^{\mathrm{g}}\end{array}$

(1) : Aynı sütunda aynı harf ile gösterilen ortalamalar arasında istatistiksel olarak fark yoktur

Sağlam buğdaylardan üretilen unlarda sedimantasyon değerleri ile gecikmeli sedimantasyon değerleri arasında önemli farklılıklar gözlenmemiştir. Gecikmeli sedimantasyon değeri sedimantasyon değerinden yüksek olmalıdır, eğer bu fark 5 ml'den daha düşük ise ilgili buğday numunesinde süne-kımı zararı vardır denmektedir (Dizlek ve ark., 2013). Analizi yapılan 19 buğday çeşidine ait unların sedimantasyon değerleri incelendiğinde (Çizelge 3) Mirzabey, Kunduru-1149 ve Çeşit 1252 çeşitlerinin süne zararına uğradığı belirlenmiştir.

\section{Buğday unlarının farinogram değerleri}

Un örnekelrinin farinogram değerleri Çizelge 4'te verilmiştir. Un örneklerinin su absorbsiyon değerleri \%67.67 (Burgaz ve Gediz 75) ile \%53.33 (Gerek 79) arasında değişkenlik göstermiştir. Gelişme süresi Bezostaja çeşidinde 6.7 dakika (d), Osmaniye çeşidinde ise $5.5 \mathrm{~d}$ gibi yüksek bir değer gösterirken diğer örneklerde 1.0-2.4 d arasında değişmiştir. Un örneklerinin stabilite süreleri arasında da önemli farklar bulunmuştur $(P<0.01)$. En yüksek stabilite değerine $(17 \mathrm{~d})$ Bezostaja çeşidinin sahip olduğu, bunu 7.7 d ile Osmaniye çeşidinin izlediği belirlenmiştir. Diğer un örneklerinin ise düşük stabilite süresine sahip oldukları gözlenmiştir. Kırmızı buğdayın stabilite süresi en düşük değer (0.9 d) olarak saptanmıştır (Çizelge 4). Aydoğan ve ark. (2012) buğday çeşitlerinin su absorbsiyonunun \%56.4-64.2, stabilite değerlerinin 1.40-4.65 d ve gelişme süresinin 2.15-4.25 d arasında değiştiğini rapor etmişlerdir. Aydoğan ve ark. (2013) buğdayın farinogramdaki su absorbsiyon değerini \%61.2, farinogram gelişme süresini $9.48 \mathrm{~d}$ olduğunu bildirmişlerdir. 
Çizelge 4. Buğday unlarının farinogram özellikleri ${ }^{(1)}$

\begin{tabular}{|c|c|c|c|c|c|}
\hline Buğday Genotipleri & $\begin{array}{l}\text { Su } \\
\text { absobsiyonu } \\
(\%)\end{array}$ & $\begin{array}{l}\text { Gelişme } \\
\text { Süresi (d) }\end{array}$ & $\begin{array}{l}\text { Stabilite } \\
\text { (d) }\end{array}$ & $\begin{array}{l}\text { Yumuşama } \\
\text { derecesi } \\
\text { (12 d sonra) }\end{array}$ & $\begin{array}{l}\text { Farinograf } \\
\text { kalite } \\
\text { numarası }\end{array}$ \\
\hline \multicolumn{6}{|c|}{ Ekmeklik Buğday Genotipleri } \\
\hline Gerek 79 & $53.33^{e(1)}$ & $1.2^{\mathrm{hl}}$ & $2.7^{\mathrm{g}}$ & $107.3^{\mathrm{fg}}$ & $30.0^{\mathrm{fg}}$ \\
\hline Bezostaja & $64.47^{\mathrm{b}}$ & $6.7^{\mathrm{a}}$ & $17.0^{a}$ & $11.0^{\prime}$ & $201.3^{a}$ \\
\hline Cumhuriyet 75 & $53.67^{e}$ & $1.8^{\mathrm{e}}$ & $7.1^{c}$ & $53.3^{k}$ & $73.3^{c}$ \\
\hline Sönmez 2001 & $58.57^{d}$ & $1.7^{\text {ef }}$ & $1.7^{\mathrm{jk}}$ & $110.0^{f}$ & $27.0^{\mathrm{fgh}}$ \\
\hline Hatay 86 & $59.87^{\mathrm{cd}}$ & $1.8^{\mathrm{e}}$ & $1.87^{i j}$ & $130.3^{\mathrm{e}}$ & $26.0^{\mathrm{gh}}$ \\
\hline Osmaniye & $60.40^{c d}$ & $5.5^{b}$ & $7.7^{\mathrm{b}}$ & $102.0^{\mathrm{g}}$ & $106.0^{b}$ \\
\hline İzmir 85 & $60.13^{\mathrm{cd}}$ & $1.7^{\text {ef }}$ & $4.7^{\mathrm{e}}$ & $70.0^{j}$ & $55.0^{d}$ \\
\hline Yunak & $58.70^{d}$ & $1.5^{\mathrm{fg}}$ & $3.1^{f}$ & $77.3^{\prime}$ & $31.7^{f}$ \\
\hline \multicolumn{6}{|c|}{ Makarnalık Buğday Genotipleri } \\
\hline Ankara 98 & $59.40^{c d}$ & $1.3^{\mathrm{gh}}$ & $5.1^{d}$ & $79.3^{\mathrm{h}}$ & $54.0^{d}$ \\
\hline Mirzabey & $58.40^{d}$ & $1.2^{\mathrm{h}}$ & $1.3^{\prime}$ & $177.3^{b}$ & $23.0^{h l}$ \\
\hline Sert Buğday (Bağıllı) & $58.10^{d}$ & $1.5^{\mathrm{fg}}$ & $2.5^{h}$ & $142.7^{d}$ & $37.0^{\mathrm{e}}$ \\
\hline Kırmızı Kazmalı Buğday & $62.30^{b c}$ & 1.9 de & $1.87^{\mathrm{ij}}$ & $75.7^{\mathrm{ij}}$ & $29.3^{\mathrm{fg}}$ \\
\hline Levante & $57.40^{d}$ & $1.5^{\mathrm{fg}}$ & $1.6^{k}$ & $1.2^{\mathrm{m}}$ & $26.0^{\mathrm{gh}}$ \\
\hline Kırmızı Buğday & $58.33^{d}$ & $1.3^{h}$ & $0.9^{m}$ & $84.7^{\mathrm{h}}$ & $19.0^{\prime}$ \\
\hline Burgaz & $67.67^{a}$ & $2.1^{d}$ & $2.01^{\prime}$ & $80.7^{\text {hl }}$ & $29.7^{\mathrm{fg}}$ \\
\hline Kızıltan & $53.80^{\mathrm{e}}$ & $1.2^{\mathrm{hl}}$ & $2.01^{\prime}$ & $106.0^{\mathrm{fg}}$ & $26.0^{\mathrm{gh}}$ \\
\hline Kunduru-1149 & $58.73^{d}$ & $1.5^{f}$ & $1.6^{\mathrm{k}}$ & $205.0^{a}$ & $25.0^{\mathrm{gh}}$ \\
\hline Çeşit 1252 & $53.37^{\mathrm{e}}$ & $1.0^{\prime}$ & $1.7^{\mathrm{jk}}$ & $154.7^{c}$ & $20.0^{\prime}$ \\
\hline Gediz 75 & $67.67^{a}$ & $2.4^{\mathrm{c}}$ & $1.5^{\mathrm{k}}$ & $132.0^{\mathrm{e}}$ & $38.0^{\mathrm{e}}$ \\
\hline
\end{tabular}

(1) : Aynı sütunda aynı harf ile gösterilen ortalamalar arasında istatistiksel olarak fark yoktur

Stabilite süresi en fazla bulunan Bezostaja çeşidinin yumuşama derecesinin en düşük (11 B.U.), Kunduru-1149 çeşidinin ise yumuşama derecesinin 205 B.U değeri ile en yüksek değeri aldığı tesbit edilmiştir (Çizelge 4). Çukurova Bölgesi ekmeklik buğday unlarının stabilite sürelerinin 4.6-11.5 d arasında değiştiği, Amanos 97 makarnalık buğday çeşidinde ise bu sürenin 1.8 dakikaya düştüğü tespit edilmiştir (Çoşkuner ve ark., 2011).

Farinograf kalite numarası unun ekmeklik kalitesini ölçmek için kullanılan bir indekstir. Farinogram üzerinde yatay olarak dakika cinsinden hesaplanır. Brabender farinograf cihazı tarafından otomatik olarak bu değer hesaplanıp grafik değeri olarak verilmektedir. Farinograf kalite numarası 65 üzerindeyse unun kalitesi çok yüksek, 50-65 arasında ise yüksek, 40-50 arasında ise yeterli, 40'ın altında ise düşük kaliteli olarak sınıflandırılabilir (Constantin ve ark., 2011; Munteanu ve ark., 2016). Ekmeklik buğday çeşitleri farinograf kalite numarası bakımından ele alındığında Bezostaja, Cumhuriyet 75 ve Osmaniye çeşitlerinin çok yüksek, İzmir 85 çeşidinin yüksek, Gerek 79, Sönmez 2001, Mirzabey, Hatay 86 ve Yunak çeşitlerinin ise düşük kaliteli buğday çeşitleri olduğu belirlenmiştir. Makarnalık buğday çeşitlerinin ise beklenildiği üzere farinograf kalite numaraları Ankara 98 çeşidi haricinde düşük bulunmuştur.

\section{Buğday unlarının SMS/Kieffer hamur ve gluten uzayabilirlik değerleri}

Buğday unlarının Kieffer değerleri Çizelge 5'te verilmiştir. Uzamaya karşı gösterilen maksimum direnç değerleri ele alındığında 22 g ile Levante 20.9 g ile de Cumhuriyet 75 çeşitlerinin en yüksek değere sahip olduğu, bunları 19.4 g ile Kırmızı Kazmalı Buğday çeşidinin izlediği, diğer taraftan $6.7 \mathrm{~g}$ ile Kunduru-1149 çeşidinin en düşük direnç değerine sahip olduğu belirlenmiştir. 
Çizelge 5. Buğday unlarının SMS/Kieffer hamur ve gluten uzayabilirlik değerleri ${ }^{(1)}$

\begin{tabular}{llll}
\hline Buğday Genotipleri & $\begin{array}{l}\text { Uzamaya karşı } \\
\text { maksimum direnç }(\mathrm{g})\end{array}$ & $\begin{array}{l}\text { Uzayabilirlik } \\
(\mathrm{mm})\end{array}$ & $\begin{array}{l}\text { Kurve altındaki } \\
\text { alan (g.s) }\end{array}$ \\
\hline Ekmeklik Buğday Genotipleri & & & \\
Gerek 79 & $13.2^{\mathrm{f}(1)}$ & $18.9^{\mathrm{c}}$ & $178.9^{\mathrm{b}}$ \\
Bezostaja & $11.3^{\mathrm{g}}$ & $61.1^{\mathrm{a}}$ & $245.1^{\mathrm{a}}$ \\
Cumhuriyet 75 & $20.9^{\mathrm{a}}$ & $19.8^{\mathrm{c}}$ & $171.9^{\mathrm{b}}$ \\
Sönmez 2001 & $14.3^{\text {ef }}$ & $16.8^{\mathrm{c}}$ & $160.4^{\mathrm{bc}}$ \\
Hatay 86 & $9.3^{\mathrm{h}}$ & $13.3^{\mathrm{c}}$ & $64.7^{\mathrm{f}}$ \\
Osmaniye & $15.8^{\mathrm{d}}$ & $39.1^{\mathrm{b}}$ & $172.5^{\mathrm{b}}$ \\
İmir 85 & $13.5^{\text {ef }}$ & $20.1^{\mathrm{c}}$ & $236.3^{\mathrm{a}}$ \\
Yunak & $14.0^{\text {ef }}$ & $16.2^{\mathrm{c}}$ & $157.4^{\mathrm{bc}}$ \\
Makarnalık Buğday Genotipleri & & & \\
Sert Buğday (Bağılı) & $13.3^{\mathrm{f}}$ & $8.4^{\mathrm{c}}$ & $64.4^{\mathrm{f}}$ \\
Mirzabey & $7.4^{\mathrm{f}}$ & $5.3^{\mathrm{c}}$ & $48.3^{\mathrm{f}}$ \\
Ankara 98 & $13.2^{\mathrm{f}}$ & $11.5^{\mathrm{c}}$ & $110.1^{\mathrm{e}}$ \\
Kırmızı Kazmalı Buğday & $19.4^{\mathrm{b}}$ & $10.6^{\mathrm{c}}$ & $113.6^{\mathrm{de}}$ \\
Levante & $22.0^{\mathrm{a}}$ & $12.7^{\mathrm{c}}$ & $127.7^{\mathrm{cde}}$ \\
Kırmızı Buğday & $14.7^{\mathrm{de}}$ & $12.5^{\mathrm{c}}$ & $132.9^{\mathrm{cde}}$ \\
Burgaz & $17.1^{\mathrm{c}}$ & $14.4^{\mathrm{c}}$ & $142.4^{\mathrm{bcde}}$ \\
Kızıltan & $9.3^{\mathrm{h}}$ & $5.5^{\mathrm{c}}$ & $49.7^{\mathrm{f}}$ \\
Kunduru-1149 & $6.7^{\mathrm{f}}$ & $1.6^{\mathrm{c}}$ & $31.4^{\mathrm{f}}$ \\
Çeşit 1252 & $9.1^{\mathrm{h}}$ & $5.5^{\mathrm{c}}$ & $40.2^{\mathrm{f}}$ \\
Gediz 75 & $10.1^{\mathrm{h}}$ & $49.9^{\mathrm{ab}}$ & $149.0^{\mathrm{bcd}}$ \\
\hline
\end{tabular}

${ }^{(1)}$ : Aynı sütunda aynı harf ile gösterilen ortalamalar arasında istatistiksel olarak fark yoktur

Farklı buğday çeşitleri uzama kabiliyetleri açısından karşılaştırıldığında aralarında istatistiksel olarak önemli farklar çıkmıştır $(P<0.01)$. Bezostaja, elastikiyeti yani uzama derecesi $(61.1 \mathrm{~mm})$ en fazla olan buğday çeşidi olarak belirlenirken, bunu $49.9 \mathrm{~mm}$ değeri ile aralarında istatistiksel olarak önemli bir fark olmayan Gediz 75 buğday çeşidi izlemiştir. Özellikle Kunduru-1149 çeşidinin elastikiyetinin yani uzama kabiliyetinin çok düşük oluşu dikkat çekici ölçüdedir. Hamurun uzama kabiliyeti üzerinde unun içerdiği gluten miktarı ve kalitesi etkilidir. Kunduru-1149 çeşidinin yaş öz, gluten indeks ve sedimantasyon değerlerine bakıldığı zaman bu değerlerin çok düşük olduğu, gecikmeli sedimantasyon değeri incelendiğinde ise süne zararına uğradığı tespit edilmiştir. Dolayısıyla uzamaya karşı gösterilen maksimum direnç, elastikiyet ve kurve altında kalan alan değerlerinin de düşük olması beklenen bir sonuçtur. Literatürdeki bazı araştırmacılar buğdayın uzayabilirlik değerinin 146-208 mm (Alava ve ark., 2007) ve $118-180.6 \mathrm{~mm}$ (Meral ve ark., 2010) arasında değiştiğini bildirmişlerdir.

En yüksek alan değerine elastikiyeti de en yüksek olan Bezostaja (245.1 g.s) çeşidi ile
İzmir 85 (236.3 g.s) çeşitlerinin sahip olduğu belirlenmiştir. En düşük alan değerine ise diğer ölçülen tüm özellikleri en düşük seviyede çıkan Kunduru-1149 (31.4 g.s) çeşidinde rastlanmıştır. Bununla birlikte Kunduru-1149 çeşidinin alan değeri ile Çeşit 1252 (40.2 g.s), Mirzabey (48.3 g.s), Kızıltan (49.7 g.s), Sert Buğday (64.4 g.s) ve Hatay 86 (64.7 g.s) çeşitlerinin alan değerleri arasında istatistiksel olarak önemli bir fark görülmemiştir ( $P>0.01)$.

\section{Dobraszczyk/Roberts hamur şişirme testi sonuçları}

Farklı buğday çeşitlerine ait unlar ile hazırlanan hamurların Dobraszczyk/Roberts hamur şişirme testi sonuçları Çizelge 6'da verilmiştir. Uzamaya karşı gösterilen direnç $(P)$ değeri açısından farklı buğday çeşitlerine ait olan hamurlar karşılaştırıldığında Burgaz çeşidinin en yüksek basınç değerine (278.3 mm) sahip olduğu, onu Kırmızı Kazmalı Buğday (208.4 mm) ve Cumhuriyet 75 (195.3 mm) çeşitlerinin izlediği, diğer taraftan Mirzabey $(22.2 \mathrm{~mm})$ ve Kunduru-1149 (35.2 $\mathrm{mm})$ çeşitlerinin en düşük direnç değerine sahip oldukları saptanmıştır. 
Çizelge 6. Buğday unlarının hamur şişirme değerleri ${ }^{(1)}$

\begin{tabular}{|c|c|c|c|}
\hline Buğday Genotipleri & $P(m m)$ & $\mathrm{L}(\mathrm{mm})$ & W (Joules * 10000) \\
\hline \multicolumn{4}{|c|}{ Ekmeklik Buğday Genotipleri } \\
\hline Gerek 79 & $53.1^{\mathrm{gh}(1)}$ & $25.7^{\mathrm{bcd}}$ & $38.8^{\text {defg }}$ \\
\hline Bezostaja & $54.6^{\mathrm{gh}}$ & $45.3^{a}$ & $96.5^{b c}$ \\
\hline Cumhuriyet 75 & $195.3^{b}$ & $21.0^{\text {cdef }}$ & $142.8^{a}$ \\
\hline Sönmez 2001 & $133.5^{d}$ & $15.0^{\text {cdefg }}$ & $87.1^{b c}$ \\
\hline Hatay 86 & $88.0^{\text {ef }}$ & $4.6^{\mathrm{fg}}$ & 26.3 efg \\
\hline Osmaniye & $67.0 \mathrm{fg}$ & $28.6 \mathrm{abc}$ & $65.5 \mathrm{cde}$ \\
\hline İzmir 85 & $142.9 \mathrm{~cd}$ & 24.5 bcde & $115.7 \mathrm{ab}$ \\
\hline Yunak & $92.1 \mathrm{e}$ & 18.1 cdefg & 59.8 cdef \\
\hline \multicolumn{4}{|c|}{ Makarnalık Buğday Genotipleri } \\
\hline Ankara 98 & $154.7^{\mathrm{cd}}$ & $5.2^{\mathrm{fg}}$ & $40.0^{\text {defg }}$ \\
\hline Mirzabey & $22.2^{\prime}$ & $0.7^{\mathrm{g}}$ & $10.0^{\mathrm{g}}$ \\
\hline Sert Buğday (Bağıllı) & $64.8^{\mathrm{fg}}$ & $0.5^{\mathrm{g}}$ & $0.0^{g}$ \\
\hline Kırmızı Kazmalı Buğday & $161.6^{c}$ & $11.0^{\text {cdefg }}$ & $70.5^{\mathrm{cd}}$ \\
\hline Levante & $166.5^{c}$ & $8.7^{\text {defg }}$ & $72.8^{\mathrm{cd}}$ \\
\hline Kırmızı Buğday & $208.4^{b}$ & $8.7^{\text {defg }}$ & $77.0 \mathrm{bcd}$ \\
\hline Burgaz & $278.3^{a}$ & $6.1^{\mathrm{efg}}$ & $93.6^{b c}$ \\
\hline Kızıltan & $47.8^{\mathrm{gh}}$ & $2.0^{\mathrm{g}}$ & $11.2^{\mathrm{g}}$ \\
\hline Kunduru-1149 & $35.2 \mathrm{hl}$ & $0.8 \mathrm{~g}$ & $15.6 \mathrm{~g}$ \\
\hline Çeşit 1252 & $66.7 \mathrm{fg}$ & $39.2 \mathrm{ab}$ & $23.9 \mathrm{fg}$ \\
\hline Gediz 75 & $72.8 \mathrm{efg}$ & $6.2 \mathrm{efg}$ & $26.7 \mathrm{efg}$ \\
\hline
\end{tabular}

(1) : Aynı sütunda aynı harf ile gösterilen ortalamalar arasında istatistiksel olarak fark yoktur

En yüksek uzama değerinin Bezostaja (45.3 mm) ve Çeşit 1252 (39.2 mm), en düşük uzama değerinin ise Sert Buğday (Bağıllı) $(0.5$ $\mathrm{mm})$, Mirzabey $(0.7 \mathrm{~mm})$, Kunduru-1149 (0.8 $\mathrm{mm})$, Kızıltan $(2.8 \mathrm{~mm})$, Hatay $86(4.6 \mathrm{~mm})$ ve Ankara $98(5.2 \mathrm{~mm})$ çeşitlerine ait olduğu belirlenmiştir (Çizelge 6).

Buğday genotiplerinin ekmeklik kalitesini ortaya çıkarmak amacıyla yapılan reolojik testlerden hamur şişirme testinin sonuçları ele alındığında; Cumhuriyet $\quad 75 \quad$ (142.8 Joules*10000) ve İzmir 85 (115.7 Joules*10000) çeşitlerinin en fazla ekmeklik enerji değerlerine sahip olduğu buna karşın Sert Buğday (Bağıllı) çeşidinin hamur yapısının çok kötü olması sebebiyle enerji değerinin ölçülemediği, Mirzabey (10.0 Joules*10000), Kızıltan (11.2 Joules *10000) ve Kunduru-1149 (15.6 Joules *10000) çeşitlerinin de çok düşük enerji değerlerine sahip oldukları belirlenmiştir (Çizelge 6).

Sonuç olarak, Göller Bölgesinden toplanan 19 buğday genotipinin yaş öz değerlerinin \%8.47 (Kızıltan) ile \% 36.17 (Bezostaja), gluten indeks değerlerinin \%0.2 (Kunduru-1149) ile \%94.9 (Ankara 98), sedimantasyon değerlerinin $9.3 \mathrm{ml}$ (Burgaz) ile $40 \mathrm{ml}$ (Bezostaja) arasında değiştiği bulunmuştur. Bu sonuçlardan da görülebileceği gibi Bezostaja hem yaş öz hem de sedimantasyon değerinin yüksek olması sebebiyle kaliteli bir ekmeklik buğday çeşidi olarak öne çıkmaktadır.

Buğday geotiplerinin gecikmeli sedimantasyon değerleri incelendiğinde Mirzabey, Sert Buğday (Bağıllı), Levante, Kunduru-1149 ve Çeşit 1252 çeşitlerinin süne zararına uğradığı belirlenmiştir.

Genel olarak makarnalık buğday çeşitlerinin reolojik özellikleri zayıf olmakla birlikte özellikle yaş öz, gluten indeks ve sedimantasyon değerleri bakımından da zayıf olan Kunduru-1149 çeşidinin reolojik olarak da çok düşük kaliteye sahip olduğu görülmüştür. Dolayısıyla yörede yetiştirilen buğday genotiplerinin un kalite özelliklerinin düşük olduğu ve yaygın olarak makarnalık buğday çeşitlerinin ekmeklik un üretiminde kullanılmasının yanlış bir uygulama olduğu kanısına varılmıştır.

\section{Teşekkür}

$\mathrm{Bu}$ çalışma; Süleyman Demirel Üniversitesi Bilimsel Araştırmalar Proje Birimi (SDÜ-BAP), tarafından 2863-M-11 no'lu proje kapsamında desteklenmiştir. Desteklerinden 
dolayı SDÜ Bilimsel Araştırmalar Proje Birimi'ne teşekkür ederiz.

\section{Kaynaklar}

AACCI Methods. 2010. AACC International Approved Methods. $11^{\text {th }}$ Edition. American Association of Cereal Chemists, Inc, St. Paul, Minnesota, USA.

Alava, J.M., Sahi, S.S., Garcia-Alvarez, J., Turob, A., Chavez, J.A., Garcia, M.J. ve Salazar, J. 2007. Use of ultrasound for the determination of flour quality. Ultrasonics, 46: 270-276.

Aydın, N., Bayramoğlu, H.O., Mut, Z. ve Özcan, H. 2005. Ekmeklik buğday (Triticum aestivum L.) çeşit ve hatlarinin karadeniz koşullarinda verim ve kalite özelliklerinin belirlenmesi. Tarım Bilimleri Dergisi, 11 (3): 257-262.

Aydoğan, S., Akçacık, A.G., Şahin, M., Kaya, Y., Koç, H. ve Ekici, M. 2012. Ekmeklik buğday unlarında alveograf, farinograf ve miksografta ölçülen reolojik özellikler arasındaki ilişkinin belirlenmesi. Süleyman Demirel Üniversitesi Ziraat Fakültesi Dergisi, 7 (1): 74-82.

Aydoğan, S., Akçacık, A.G., Şahin, M., Önmez, H., Demir, B. ve Yakışır, E. 2013. Ekmeklik buğday çeşitlerinde fizikokimyasal ve reolojik özelliklerin belirlenmesi. Tarla Bitkileri Merkez Araştırma Enstitüsü Dergisi, 22 (2): 7485.

Chin, N.L. ve Campbell, G.M. 2005. Dough aeration and rheology: Part 2. Effects of flour type, mixing speed and total work input on aeration and rheology of bread dough. Journal of the Science of Food and Agriculture, 85: 2194-2202.

Constantin G., Voicu G., Rusnescu C.O. ve Tefan E.M. 2011. Researches on Rheological Characteristics of Dough of Wheat Flour and their Changes During Storage. Bulletin UASVM Agriculture, 68(2)/2011.

Çoşkuner, Y., Karababa, E. ve Ercan, R. 2011. Çukurova bölgesinde yetiştirilen bazi buğday çeşitlerinin iki katli yassi ekmek üretimine uygunluğunun belirlenmesi. Electronic Journal of Food Technologies 6 (1):1-12.

Diepenbrock, W., Ellmer, F., \& Leon, J. 2005. Ackerbau, Pflanzenbau und Planzenzüchtung, UTB2629, Verlag Eugen Ulmer, Stuttgart.
Dizlek, H., Gül, H., Özer, M.S., Aksoy, M. ve Özkan, H. 2013. Çukurova Üniversitesi Ziraat Fakültesi Tarla Bitkileri Bölümü tarafından yetiştirilen 30 farklı ekmeklik buğday çeşidinin değerlendirilmesi I. Fiziksel ve teknolojik özellikler. Dünya Gıda Dergisi, 18 (1): 76-88.

Dizlek, H., Gül, H., Özer, M.S., Aksoy, M. ve Özkan, H. 2014. Genetik olarak iyileştirilerek yetiştirilen 30 farklı ekmeklik buğday çeşidinin değerlendirilmesi II. reolojik ve ekmek özellikleri. Dünya Gıda Dergisi, 19 (7): 81-93.

Egesel, C.Ö., Kahrıman F., Tayyar, Ş. ve Baytekin, H. 2009. Ekmeklik buğdayda un kalite özellikleri ile dane veriminin karşılıklı etkileşimleri ve uygun çeşit seçimi. Anadolu Tarım Bilim Dergisi, 24 (2): 76-83.

Eser, D., Geçit, H.H., ve Emekliler, H.Y. 1987. Türkiye'nin tahil gen kaynaklari bakimindan önemi. Türkiye Tahıl Sempozyumu, Bursa (1987). Ss:347-352.

Greenaway, W., Neustadt, M. H. ve Zeleny, L. 1965. Communication to the Editor: $A$ test for stink bug damage in wheat. Cereal Chemistry, 42 (6): 577-579.

Hazen, S.P.ve Ward, R.W. 1997. Variation in Soft Winter Wheat Characteristics Measured by the Single Kernel Characterization System. Crop Science, 37: 1079-1086.

Kahrıman, F. ve Egesel, C.Ö. 2011. Farklı Ekmeklik Buğday Çeşitlerinin Agronomik ve Kalite Özellikleri Bakımından Değerlendirilmesi. Ordu Üniversitesi Bil. Tek. Derg., 1(1): 22-35.

Kara, B. ve Akman, Z. 2008. Comparison of Yield and some Quality Components of Wheat Cultivars and Landraces. Turkish Journal of Field Crops, 13: 12-23.

Kara, B., Dizlek, H., Uysal, N. ve Gül, H. 2009. Buğdayda geç dönemde azot uygulamasının tane protein ve unda bazı fizikokimyasal özelliklere etkisi. Süleyman Demirel Üniversitesi Fen Bilimleri Enstitüsü Dergisi, 13 (1): 25-32.

Kieffer, R., Wieser, H., Henderson, M.H. ve Graveland, A. 1998. Correlations of the bread making performance of wheat flour with rheological measurements on a micro-scale. Journal of Cereal Science, 27: 53-60. 
Menderis, M., Atlı, A., Kökten, M. ve Kılıç, $H$. 2008. Gluten indeks değeri ve yaş gluten/protein oranı ile ekmeklik buğday kalite değerlendirilmesi. Harran Üniversitesi Ziraat Fakültesi Dergisi, 12 (3): 57-64.

Meral, R., Yıldız, Ö. ve Doğan, İ.S. 2010. Unların reolojik özelliklerinin belirlenmesinde tekstür analiz cihazının kullanımı ve sonuçların ekstensograf değerleri ile karşılaştırılması. Gıda Teknolojileri Elektronik Dergisi, 5(3): 17-24.

Munteanu M.G., Voicu G., Ungureanu N., Zăbavă B., lonescu M., Constantin G.A. ve Istrate I. 2016. Methods for Determining the Characteristics of Flour and Dough. Conference: 5th International Conference on Thermal Equipment, Renewable Energy and Rural Development TE-RE-RD.

Reçber, A. 2011. İleri Ekmeklik Buğday (Triticum aestivum L.) Hatlarinin Bazi Agronomik ve Kalite Özelliklerinin Belirlenmesi (Yüksek Lisans Tezi). Ege Üniversitesi, Fen Bilimleri Enstitüsü, 90s, İzmir.

Sözen, E. ve Yağdı, K. 2005. Bazı İleri Makarnalik Buğday (Triticum durum Desf.) Hatlarinin Kalite Özelliklerinin Belirlenmesi. Uludağ Üniversitesi Ziraat Fakültesi Dergisi, 19(2): 69-81.

Topdemir, P.Ç. 2004. Türkiye'de yetiştirilen bazi ekmeklik buğday çeşitlerinin un ve ekmek kalitelerinin belirlenmesi (Yüksek Lisans Tezi). Celal Bayar Üniversitesi, Fen Bilimleri Enstitüsü, İzmir.

TÜik. 2019. Türkiye İstatistik Kurumu (Erişim tarihi: 31.07.2019).

Yağdı, K. 2004. Bursa Koşullarinda Geliştirilen Ekmeklik Buğday (Triticum aestivum L.) Hatlarinin Bazi Kalite Özelliklerinin Araştirilması. Uludağ Üniversitesi Ziraat Fakültesi Dergisi, 18 (1): 11-23. 